\title{
Upaya Meningkatkan Kemampuan Membaca Permulaan Melalui Media Gambar Pada Siswa Kelas I SDN 5 Bulango Selatan
}

\author{
Amna Dunda \\ Guru Kelas I SDN 5 Bulango Selatan \\ amnadunda@gmail.com
}

Received: 04 March 2021; Revised: 26 April 2021; Accepted: 28 July 2021

DOI: http://dx.doi.org/10.37905/aksara.7.3.1179-1184.2021

\begin{abstract}
Abstrak
Penelitian ini bertujuan untuk meningkatkan kemampuan membaca lancar melalui media gambar. Subyek penelitian adalah guru dan siswa kelas I SDN 5 Bulango Selatan yang berjumlah 22 siswa. Sumber data penelitian ini adalah siswa dan guru. Bentuk penelitian ini adalah Penelitian Tindakan Kelas (PTK). Teknik pengumpulan data yang digunakan melalui observasi, dokumentasi dan unjuk kerja. Teknik uji validitas data menggunakan bentuk trianggulasi sumber dan trianggulasi data. Teknik analisis data menggunakan teknik analisis interaktif yang terdiri dari 3 komponen yaitu reduksi data, penyajian data dan penarikan kesimpulan. Prosedur penilaian meliputi tahap identifikasi masalah, persiapan, tindakan, pengamatan dan penyusunan rencana. Proses penelitian dilaksanakan dalam 2 siklus, masing-masing siklus terdiri dari 4 tahap, yaitu: perencanaan, tindakan, pengamatan dan refleksi. Hasil penelitian menunjukkan adanya peningkatan kemampuan membaca lancar belajar siswa. Adapun peningkatan hasil pembelajaran dapat dilihat dari perolehan nilai siswa dalam pembelajaran Bahasa Indonesia yang meningkat dari siklus I dan siklus II. Pada siklus I nilai rata-rata kelas hasil belajar siswa sebesar $68,18 \%$ dan pada siklus II sebesar $86,36 \%$.

Hasil pengolahan data kemampuan membaca lancar pada siklus I dari 22 siswa hanya 3 siswa atau 13,6\% yang mencapai ketuntasan belajar. Sedangkan pada siklus I terjadi peningkatan yaitu ada 15 siswa atau $68,18 \%$ yang mencapai ketuntasan belajar. Pada siklus II mencapai ketuntasan $86,36 \%$ yaitu siswa yang tuntas ada 19 dan yang belum tuntas hanya 3 anak.

Peningkatan kemampuan membaca lancar Media gambar pada pembelajaran Bahasa Indonesia kelas I dapat meningkatkan kemampuan membaca lancar siswa. Semoga media ini bisa menjadi salah satu alternatif media pembelajaran bagi rekan-rekan guru.
\end{abstract}

Kata Kunci: Peningkatan kemampuan membaca lancar, Media gambar.

\section{PENDAHULUAN}

Membaca merupakan suatu aktivitas yang dilakukan untuk mendapatkan Sebuah informasi, memperoleh ilmu dan pengetahuan serta pengalaman- pengalaman baru. Pada hakikatnya, aktivitas membaca terdiri dari dua bagian, yaitu membaca sebagai proses dan membaca sebagai produk. Membaca sebagai proses mengacu pada aktivitas fisik dan 
mental. Sedangkan membaca sebagai produk mengacu pada konsekuensi dari aktivitas yang dilakukan pada saat membaca ( Puji Santosa dkk, 2005: 6.3).

Kegiatan membaca merupakan aktivitas yang unik dan rumit, sehingga seseorang tidak dapat melakukan hal tersebut tanpa mempelajarinya, terutama anak usia sekolah dasar yang baru mengenal huruf atau kata-kata. Problem umum yang dihadapi anak dalam membaca adalah pada pelaksanaan pengajaran membaca, guru sering kali dihadapkan anak yang mengalami kesulitan, baik yang berkenaan dengan hubungan huruf, suku kata, kata, kalimat sederhana, maupun ketidakmampuan anak memahami isi bacaan.

Penggunaan model pembelajaran dan media sangat membantu dalam pengajaran membaca permulaan bagi siswa kelas satu SD merupakan hal yang mutlak diperlukan, anak kelas satu SD yang pada umumnya baru berusia enam tahun masih berada pada taraf berfikir konkret, yaitu anak akan mudah mengenali hal-hal yang bersifat nyata. Disamping itu, dengan alat bantu yang digunakan oleh guru secara bervariasi akan membangkitkan minat siswa dalam mengikuti pelajaran. Salah satu media yang memungkinkan digunakan oleh guru dalam pengajaran membaca permulaan ini adalah melalui media gambar.

Pembelajaran membaca permulaan di SDN 5 Bulango Selatan Kecamatan Bulango Selatan selama ini masih belum mengoptimalkan media pembelajaran yang ada di sekolah. Proses pembelajaran masih menggunakan media konvensional yaitu dengan menggunakan papan tulis dan pembelajaran hanya berpusat kepada guru. Hal ini menyebabkan kemampuan membaca permulaan siswa masih sangat rendah. Media gambar yang ada di sekolah tidak dipergunakan sebagaimana mestinya dan hanya disimpan dalam lemari.

Dari uraian latar belakang di atas, peneliti tertarik untuk mengadakan penelitian tindakan kelas dengan judul "Peningkatan Kemampuan Membaca Permulaan Siswa Kelas I SDN 5 Bulango Selatan Kecamatan Bulango Selatan melalui Media gambar".

Berdasarkan teori dan kerangka pemikiran di atas, maka dapat dirumuskan hipotesis tindakan/dugaan sementara sebagai berikut : Melalui penggunaan media gambar dalam pembelajaran bahasa Indonesia (membaca permulaan) dapat meningkatkan kemampuan membaca permulaan siswa kelas 1 SD Negeri 5 Bulango Selatan Kecamatan Bulango Selatan Kabupaten Bone Bolango.

\section{METODE PENELITIAN}

Data yang digunakan dalam penelitian ini adalah kualitatif, yaitu data-data yang diperoleh pada kondisi awal, kondisi siklus I, dan kondisi siklus II yang berupa data primer yaitu data yang diperoleh dari subjek penelitian, dalam hal ini adalah data dari siswa. Data yang lain adalah data sekunder yaitu data yang dapat diperoleh dari selain siswa misalnya dari pendidik yang lain selaku peneliti maupun atasan peneliti yaitu Kepala Sekolah.

Peneliti disini memilih Penilitian Tindakan Kelas karena Penelitian Tindakan Kelas yang paling relevan dan tepat untuk memecahkan masalah diatas. Setidaknya ada empat alasan mendasar mengapa Penelitian Tindakan Kelas dipandang sebagai suatu terobosan yang tepat dalam penelitian pendidikan.

1. Berbagai pendekatan penelitian yang selama ini digunakan cenderung pada jenis penelitian dasar.

2. Biasanya penelitian yang dilakukan jarang bersentuhan langsung dengan masalah- 
masalah praktis di sekolah, bahkan guru dan personalia sering diperlakukan sebagai objek dan bukan sebagai subjek.

3. Penyebaran hasil penelitian biasanya membutuhkan waktu yang relatif lama.

4. Peningkatan kualitas pembelajaran perlu segera mendapat perhatian pemecahanya yang dilakukan dengan pendekatan keilmuan dan penelitian.

Subyek dan Obyek Penelitian

a. Subyek Penelitian

1) Siswa kelas I (satu) sebagai subyek penerima tindakan. Siswa kelas I SDN 5 Bulango Selatan berjumlah 22 siswa. Terdiri dari 9 siswa putra dan 13 siswa putri.

2) Guru kelas I sabagai subyek pelaksana tindakan. Karena kelas I masih banyak siswa yang belum bisa membaca.

b. Obyek Penelitian

1) Peningkatan keterampilan membaca lancar.

2) Menggunakan media Gambar.

Teknik dan Instrumen Pengumpulan Data

a. Teknik Pengumpulan Data

1) Observasi

Observasi atau pengamatan merupakan suatu teknik atau cara mengumpulkan data dengan jalan mengadakan pengamatan terhadap kegiatan yang sedang berlangsung (Syaodih Sukmadinata Nana, 2010:220).

Observasi atau pengamatan juga dilakukan oleh guru sebagai peneliti memperoleh gambaran secara cermat tentang tindakan yang sedang dilakukan dan kemudian mendokumentasikan pengaruh atau dampak dari tindakan tersebut. Guru sebagai peneliti tindakan kelas harus mengobservasi atau mengamati dengan cermat, mengobservasi pengaruh tindakan tersebut baik yang disengaja maupun tidak disengaja, keadaan dan kendala tindakan yang ada, bagaimana tindakan tersebut menghambat atau mempermudah tindakan yang telah direncanakan.

2) Dokumen

Studi dokumen merupakan suatu teknik pengumpulan data dengan menghimpun dan menganalisis dokumen-dokumen, baik dokumen tertulis, gambar maupun elektronik. Dokumen yang dihimpun dipilih yang sesuai dengan tujuan dan fokus masalah.

Dokumen merupakan bahan tertulis yang digunakan sebagai sumber data. Kajian Dokumen yang digunakan sebagai sumber data adalah Rencana Pelaksanaan Pembelajaran (RPP), Silabus, dan hasil tes. Dokumentasi sangat penting karena sebagai bukti fisik adanya kegiatan penelitian tindakan kelas (Syaodih Sukmadinata Nana, 2010:221).

3) Unjuk Kerja

Penilaian unjuk kerja merupakan penilaian yang dilakukan dengan mengamati kegiatan peserta didik dalam melakukan suatu pekerjaan atau tugas. Tujuan penilaian unjuk kerja adalah untuk mengetahui apa yang siswa ketahui dan apa yang mereka lakukan. Mengukur penguasaan siswa. Autentik artinya realistis atau sesuai dengan kehidupan nyata. Penilaian ini cocok digunakan untuk menilai ketercapaian penguasaan kompetensi yang menuntut peserta didik melakukan tugas tertentu, seperti: praktik sholat, olahraga, bernyanyi, membaca, 
diskusi dll. Cara penilaian ini dianggap lebih autentik daripada tes tertulis, karena apa yang dinilai lebih mencerminkan kemampuan peserta didik yang sebenarnya (Syaodih Sukmadinata Nana, 2010:233).

\section{PEMBAHASAN}

Pada pelaksanaan pembelajaran Pra siklus hanya menggunakan media gambar di papan tulis. Keaktifan membaca lancar pada pembelajaran Pra siklus hanya mencapai ketuntasan 13,60 \% dari 22 siswa berarti siswa yang mencapai ketuntasan hanya 3 anak.

Pada pelaksanaan pembelajaran Siklus I sudah menggunakan media gambar di papan tulis dan menggunakan LCD. Pada pembelejaran ini siswa sudah mulai aktif. Dibuktikan dengan siswa sudah mau membaca di depan kelas dengan suara nyaring. Keaktifan membaca lancar pada pembelajaran Siklus I sudah mulai terlihat dengan pencapaian ketuntasan 68,18 \% dari 22 siswa. Berarti siswa yang mencapai ketuntasan meningkat menjadi 15 anak. Pada pelaksanaan pembelajaran Siklus II menggunakan media gambar di papan tulis dan menggunakan LCD di tambah buku bacaan bergambar. Pada pembelajaran ini siswa semakin aktif. Dibuktikan dengan satu persatu siswa mampu membaca lancar dengan suara nyaring, intonasi yang tepat, sudah mampu membaca tanda jeda, dan sudah mampu membaca kalimat yang panjang. Keaktifan membaca lancar pada siklus II ini mencapai peningkatan menjadi 86,36 \% dari 22 siswa. Berarti siswa yang mencapai ketuntasan keaktifan membaca lancar berjumlah 19 anak dan hanya 3 anak yang masih belum tuntas.

Hasil pengolahan data keaktifan membaca lancar pada siklus I dari 22 siswa hanya 3 siswa atau 13,6\% yang mencapai ketuntasan belajar. Sedangkan pada siklus I terjadi peningkatan yaitu ada 15 siswa atau $68,18 \%$ yang mencapai ketuntasan belajar. Pada siklus II mencapai ketuntasan 86,36\% yaitu siswa yang tuntas ada 19 dan yang belum tuntas hanya 3 anak.

Berdasarkan uraian teori di atas, media gambar bisa meningkatkan keaktifan belajar siswa "Belajar adalah suatu aktivitas latihan dan kegiatan anak untuk mendapatkan pengalaman. Dalam hal ini anak diposisikan sebagai individu yang dinamis dan bukan individu yang pasip"'(Surtikanti dan Joko Santoso, 2008:12). Kondisi awal siswa kelas I SDN 5 Bulango Selatan sebelum diberi tindakan kelas menunjukkan bahwa keaktifan membaca siswa belum baik. Hal ini dapat terlihat dari hasil nilai siswa yang masih rendah. Guru mengajar dengan metode konvensional dan mengharapkan siswa duduk, diam, dengar, catat, dan menghafal. Guru kurang kreatif dalam memilih media pembelajaran sehingga keaktifan anak untuk membaca lancar rendah hasilnya., siswa bersikap pasif dalam pembelajaran, siswa takut dan malu bertanya pada guru mengenai materi yang kurang dipahami. Selain itu, siswa kurang bergairah dan bersungguh-sungguh dalam belajar membaca. Siswa juga sangat malas untuk belajar membaca Hal tersebut sangat mempengaruhi keaktifan belajar membaca lancar siswa.

Upaya untuk meningkatkan keaktifan membaca lancar siswa kelas I SDN 5 Bulango Selatan adalah dengan menerapkan media gambar. Setelah mengetahui media pembelajaran ini, guru kelas yang lain juga sangat antusias untuk segera melaksanakannya. Dalam pelaksanaannya, guru selalu memberikan motivasi dan dorongan kepada para siswa untuk aktif dalam pelaksanaan pembelajaran. Selain itu, guru memberikan bimbingan dan arahan kepada siswa dalam kegiatan belajar mengajar agar tujuan pembelajaran yang diharapkan dapat tercapai. Siswa pun sangat antusias dalam 
belajar membaca. Keaktifan membaca lancar siswa kelas I SDN 5 Bulango Selatan meningkat yang dapat meningkatkan pula hasil belajarnya.

\section{KESIMPULAN}

Berdasarkan hasil penelitian yang telah dilakukan dapat disimpulkan bahwa Penelitian Tindakan Kelas (PTK) membawa dampak positif dalam pembelajaran. Dari hasil Penelitian Tindakan Kelas yang penulis lakukan, menunjukkan dengan jelas baik secara teoritik maupun kenyataan bahwa melalui penerapan media gambar dapat meningkatkan keaktifan membaca lancar pada siswa kelas I SDN 5 Bulango Selatan Kecamatan Bulango Selatan Kabupaten Bone Bolango.

Dengan demikian sebagai kesimpulan akhir dalam Penelitian Tindakan Kelas ini adalah sebagai berikut:

1. Dengan menggunakan media gambar, keaktifan membaca lancar dan belajar siswa meningkat dari siklus ke siklus.

2. Dengan menggunakan media gambar proses pembelajaran yang dilakukan guru menjadi lebih aktif dan kreatif dan membuat siswa senang sehingga tujuan pembelajaran tercapai dengan baik.

3. Dengan menggunakan media gambar siswa lebih tertarik untuk belajar membaca.

\section{DAFTAR PUSTAKA}

Depdiknas. (2004). Penilaian. Jakarta: Departemen Pendidikan Nasional.

Faizalnizbah (2013). Pengertian membaca. Tersedia: http://faizalnizbah.blogspot.sg/2013/08/pengertian-membaca.html [6 Januari 2014]

Haryanto, S.Pd (2012). Pengertian Media Pembelajaran. Tersedia: http://belajarpsikologi.com/pengertian-media-pembelajaran/ [6 Januari 2014].

Hudaita (2009) Pembelajaran Membaca Permulaan Tersedia http://hudaita.blogspot.com/2009/01/pembelajaran-membaca-permulaan dengan.html/ (Diakses 05 Januari 2014)

Mbah Brata (2009). Pembelajaran membaca permulaan Tersedia: http://mbahbrataedu.blogspot.com/2009/08/pembelajaran-membaca-permulaan-melalui.html/ (Diakses 05 Januari 2014)

Muhammad faiq (2013) . Instrumen untuk menilai media pembelajaran berbasis teks. Tersedia :http://penelitiantindakankelas.blogspot.com/2013/10/contoh-instrumenuntuk-menilai-media-pembelajaran-berbasis-teks.html [7 januari 2014]

Puji Santosa, dkk (2005). Materi dan Pembelajaran Bahasa Indonesia . Jakarta : Universitas Terbuka

Slamet Hariadi (2013). Pengertian cara dan makna membaca Tersedia : http://selamethariadi.com/pengertian-cara-dan-makna-membaca/ [6 Januari 2014]

Teguh Prasetyo (2009). Pembelajaran membaca dan membaca permulaan. Tersedia : http://teguhs-atu.blogspot.com/2009/11/pembelajaran-membaca-danmembaca.html [7 Januari 2014] http://gudangartikels.blogspot.com /2011/08/pengertian-dan-tujuan-membaca-permulaan.html (Diakses Tanggal 10 Januari 2014) 
AKSARA: Jurnal Ilmu Pendidikan Nonformal

P-ISSN 2407-8018 E-ISSN 2721-7310 DOI prefix $\underline{10.37905}$

Volume 07, (03) September 2021

http://ejurnal.pps.ung.ac.id/index.php/Aksara 